\title{
PENGARUH BUDAYA ORGANISASI DAN KEPUASAN KERJA TERHADAP KINERJA KARYAWAN PT. BANK TABUNGAN NEGARA (PERSERO) TBK. KANTOR CABANG MEDAN
}

Fauzi

\author{
Dosen Fakultas Ekonomi, Universitas Islam Sumatera Utara, Indonesia \\ Email: Fauziuisu@gmail.com
}

\begin{abstract}
The formulation of the problem in this thesis is how the influence of organizational culture on the performance of employees of PT. State Savings Bank (Persero) Tbk, how the influence of job satisfaction on the performance of employees of PT. Bank Tabungan Negara (Persero) Tbk, how the influence of organizational culture and job satisfaction on the performance of employees of PT. State Savings Bank (Persero) Tbk. The purpose of this study was to determine and analyze organizational culture on the performance of employees of PT. State Savings Bank (Persero) Tbk, the effect of job satisfaction on the performance of employees of PT. State Savings Bank (Persero) Tbk, the influence of organizational culture and job satisfaction on the performance of employees of PT. State Savings Bank (Persero) Tbk.

The population in this study were all employees of PT. State Savings Bank (Persero) Tbk. The Medan Branch Office is 62 employees and the sample is the total population. Data obtained through agency data, library data and literature. The writer used the data collection technique through interviews and document studies. The data analysis technique was done by the writer through descriptive analysis method and multiple linear regression analysis method.

The results of this study explain that the performance of the employees of PT. Bank Tabungan Negara (Persero) Tbk Medan Branch can be improved through several factors, including organizational culture and job satisfaction. The more comfortable employees are with the organizational culture, the more their performance will be. The higher the level of job satisfaction, the higher the employee's performance. This of course will have an effect on increasing company profits. Partially, the variables of organizational culture and job satisfaction each have a significant influence on employee performance. Simultaneously, organizational culture and job satisfaction have a significant influence on the performance of employees of PT. State Savings Bank (Persero) Tbk Medan
\end{abstract}

Keywords: Organizational Culture, Job Satisfaction, Performance.

\section{PENDAHULUAN}

Sumber daya manusia (SDM) merupakan salah satu kunci penentu keberhasilan organisasi. Sumber Daya Manusia (SDM) yang baik, berkualitas, dan potensial menjadi kebutuhan perusahaan atau organisasi. Setiap perusahaan mencari dan merekrut karyawan dengan SDM yang baik untuk dapat meningkatkan keefektivitasan organisasi dan memperoleh hasil kerja untuk mencapai tujuan organisasi atau perusahaan.

Setiap organisasi bukan hanya membutuhkan SDM yang berkualitas tetapi juga membutuhkan karyawan yang siap melakukan pekerjaan lebih dari sekedar tugas biasa, karyawan yang akan memberikan kinerja melebihi harapan. Dalam dunia kerja 
yang dinamis seperti sekarang ini, dalam hal ini tugas semakin sering dikerjakan dalam tim dan fleksibilitas sangat penting, organisasi menjadi sangat membutuhkan karyawan yang mampu menampilkan kinerja yang baik.

Nurlaila (2014:71) menyebutkan kinerja merupakan suatu hal yang bersifat individual, karena setiap karyawan memiliki tingkat kemampuan yang berbeda dalam mengerjakan tugasnya. Kinerja tergantung pada kombinasi antara kemampuan, usaha, dan kesempatan yang diperoleh. Kinerja merupakan hasil atau keluaran dari suatu proses.

Rivai (2011: 309) menyatakan kinerja karyawan dapat berjalan baik dapat dipengaruhi oleh kerjasama antar karyawan. Untuk itu kerjasama yang harmonis antar karyawan harus diciptakan. Pada hakikatnya kinerja adalah sesuatu yang bersifat indivudu, dikarenakan setiap karyawan mempunyai kemampuan dan keahlian yang serta pengalaman yang berbeda-beda dalam melaksanakan tugas serta kewajiban yang dibebankan kepadanya. Kinerja seorang pegawai bergantung pada kemampuan, usaha, dan kesempatan yang diperoleh setiap pegawai. Kinerja adalah perbuatan nyata yang ditunjukkan setiap orang sebagai prestasi kerja yang dihasilkan oleh pegawai sesuai dengan tugasnya.

Berdasarkan pengamatan awal yang peneliti lakukan di PT. Bank Tabungan Negara (Persero) Tbk. Kantor Cabang Medan perilaku keseharian karyawan dalam bekerja masih sangat rendah yang mengakibatkan rasa memiliki terhadap organisasi masih belum optimal. Motivasi yang dirasakan masih belum optimal juga sehingga masih ditemukan karyawan yang kurang semangat di dalam melaksanakan pekerjaannya yang juga mengakibatkan kepuasan kerja juga belum maksimal sehingga kinerja pegawai yang diharapkan masih belum terpenuhi.

Salah satu faktor yang dapat mempengaruhi kinerja itu sendiri adalah budaya organisasi. Seorang karyawan akan merasa nyaman bekerja apabila nilai-nilai yang mereka anut sesuai dengan nilai-nilai yang diterapkan oleh perusahaannya. Hal ini akan membuat para karyawan mudah untuk beradaptasi dengan lingkungan perusahaan, sehingga karyawan akan termotivasi dan meningkatkan kinerja mereka lagi dengan lebih baik.

Menurut Sutrisno (2011:2) untuk menyatukan visi dan misi antara perusahaan dan karyawan diperlukan budaya organisasi yang kuat. Budaya Organisasi merupakan suatu sistem dari nilai-nilai, keyakinankeyakinan, asumsi-asumsi, atau norma-norma yang telah lama berlaku, disepakati dan diikuti dalam organisasi sebagai pedoman perilaku dan pemecahan masalah organisasinya. Tidak ada pribadi yang sama, tidak ada budaya organisasi yang identik. Para ahli dan konsultan mempercayai bahwa perbedaan budaya memiliki pengaruh yang besar pada kinerja organisasional dan kualitas kehidupan kerja yang dialami oleh anggota organisasi.

Menurut Siagian (2013:16), budaya organisasi diartikan sebagai pola landasan berpikir bersama suatu kelompok dimana telah digunakannya untuk menyelesaikan masalah yang sedang dihadapi yang telah berjalan cukup baik untuk dianggap sah sehingga nantinya perlu ditularkan kepada anggota baru sebagai upaya yang benar untuk memahami, berpikir, serta merasa terkait tentang masalah organisasi menjadi masalah semua anggota.

Menurut Rucky (2015:95) budaya organisasi merupakan kumpulan sistem nilai yang diakui dan dibuat oleh semua anggotanya. Mangkunegara (2013: 150) menyebutkan budaya organisasi merupakan aspek lingkungan internal yang sangat penting yang nantinya berdampak pada pencapaian hasil yang baik atau tidaknya organisasi tersebut. Budaya organisasi melibatkan harapan, nilai, dan sikap bersama yang berpengaruh terhadap individu, kelompok, dan proses dalam suatu organisasi.

Berdasarkan hasil observasi di PT. Bank Tabungan Negara (Persero) Tbk. Kantor Cabang Medan terkait budaya kerja ditemukan adanya permasalahan antara lain masih terdapatnya perilaku budaya organisasi pegawai yang sangat rendah, kurangnya teladan dari pimpinan dalam hal datang dan pulang kerja tepat pada waktunya sehingga hal tersebut membudaya atau menjadi tradisi 
dikalangan pegawai sehingga banyak pegawai yang datang dan pulang juga tidak tepat waktunya.

Budaya organisasi terbukti berpengaruh terhadap kinerja karyawan seperti penelitian yang telah dilakukan oleh Satriyawan (2018), hasil penelitian menunjukkan bahwa budaya organisasi berpengaruh positif dan signifikan terhadap kinerja karyawan. Karyawan yang diharapkan mampu meningkatkan kinerjanya ternyata cenderung tidak meningkat bahkan menurun diduga penyebab permasalahan ini adalah budaya yang diterapkan organisasi kurang baik. Seharusnya budaya organisasi secara tidak langsung sangat bermanfaat dalam membentuk perilaku serta inisiatif individu demi pencapaian tujuan organisasi.

Faktor lain yang mempengaruhi kinerja adalah kepuasan kerja, dengan meningkatkan kepuasan kerja diharapkan karyawan dapat bekerja secara produktif dan profesional sehingga kinerja yang dicapainya akan lebih memuaskan. Menurut Matutina (2015:159) kepuasan kerja adalah kondisi menyenangkan atau secara emosional positif berasal dari penilaian seseorang atas pekerjaannya atau pengalaman kerjanya. Kepuasan kerja juga bisa diartikan keadaan emosional yang menyenangkan atau tidak menyenangkan dngan mana para karyawan memandang pekerjaan mereka.

Kepuasan kerja juga merupakan salah satu variabel yang mempengaruhi tingkat kinerja para karyawan. Dengan kepuasan kerja yang diperoleh para karyawan, diharapkan kinerja para karyawan semakin meningkat sehingga tujuan perusahaan dapat tercapai. Kepuasaan kerja merupakan cerminan dari perasaan pekerja terhadap pekerjaannya. Hal ini tampak dalam sikap positif pekerja terhadap pekerjaan yang dihadapi dan lingkungannya. Sebaliknya, kayawan yang tidak puas akan bersikap negatif terhadap pekerjaan dan bentuknya berbeda-beda antara karyawan satu dengan yang lainnya. Adapun ketidakpuasan kerja karyawan seharusnya dapat dideteksi oleh perusahaan.

Kepuasan terhadap pekerjaan akan membawa karyawan mempunyai rasa tanggung jawab yang tinggi terhadap pekerjaannya dan rasa memiliki terhadap perusahaan sehingga karyawan akan lebih rela melakukan pekerjaan yang melebihi dari tugas biasa. Namun, masalah yang timbul dalam pekerjaan yang dilakukan karyawan adalah terlalu banyaknya beban kerja yang menuntut para karyawan. Sehingga para karyawan tersebut tidak sepenuh hati dalam menjalankan tugas di perusahaan. Tentu saja hal ini

mengakibatkan kurangnya kesadaran karyawan dalam menjalankan tugasnya karena tidak adanya kepuasan kerja yang dirasakan oleh para karyawan sehingga minimbulkan penurunan jumlah karyawan, penurunan tingkat kehadiran serta bertambahnya jumlah karyawan yang datang terlambat.

Moekijat (2015:33) menyatakan bahwa kepuasan kerja menyebabkan peningkatan kinerja, sehingga pekerja yang puas akan lebih produktif dalam bekerja. Demikian juga dengan Wirawan (2015:699) yang menyatakan bahwa perasaan dan sikap positif atau negatif orang terhadap pekerjaannya membawa implikasi pengaruh terhadap dirinya dan organisasi. Jika orang puas terhadap pekerjaannya ia menyukai dan termotivasi untuk melaksanakan pekerjaannya dan kinerjanya tinggi, sebaliknya jika tidak puas dengan pekerjaannya ia tidak termotivasi untuk melaksanakan pekerjaannya dan kinerjanya rendah. Kepuasan kerja merupakan kondisi menyenangkan atau secara emosional positif yang berasal dari penilaian seseorang atas pekerjaannya atau pengalaman kerjanya. Kepuasan kerja merupakan suatu perasaan positif tentang pekerjaan seseorang yang merupakan hasil dari sebuah evaluasi karakteristiknya.

Hasil survei awal dapat dijelaskan bahwa kepuasan kerja diindikasikan menjadi penyebab kinerja yang kurang maksimal pada karyawan PT. Bank Tabungan Negara (Persero) Tbk. Kantor Cabang Medan. Hasil penelitian yang dilakukan oleh Javed, Balouch dan Hassan (2014) menemukan bahwa kepuasan kerja secara signifikan berpengaruh terhadap kinerja. Demikian halnya dengan Wijaya (2018) yang membuktikan bahwa kepuasan kerja berpengaruh positif dan signifikan terhadap kinerja karyawan. 
Berdasarkan fenomena tersebut maka maka peneliti terdorong untuk mengangkat permasalahan ini dalam bentuk penelitian dengan judul : "Pengaruh Budaya

Organisasi dan Kepuasan Kerja Terhadap Kinerja Karyawan PT. Bank Tabungan Negara (Persero) Tbk. Kantor Cabang Medan".

Berdasarkan uraian latar belakang diatas maka rumusan masalah dari penelitian ini adalah sebagai berikut :

1. Bagaimana pengaruh budaya organisasi terhadap kinerja karyawan PT. Bank Tabungan Negara (Persero) Tbk. ?

2. Bagaimana pengaruh kepuasan kerja terhadap kinerja karyawan PT. Bank Tabungan Negara (Persero) Tbk. ?

3. Bagaimana pengaruh budaya organisasi dan kepuasan kerja terhadap kinerja karyawan PT. Bank Tabungan Negara (Persero) Tbk. ?

Adapun tujuan dalam penelitian ini adalah sebagai berikut :

1. Untuk mengetahui dan menganalisis pengaruh budaya organisasi terhadap kinerja karyawan PT. Bank Tabungan Negara (Persero) Tbk.

2. Untuk mengetahui dan menganalisis pengaruh kepuasan kerja terhadap kinerja karyawan PT. Bank Tabungan Negara (Persero) Tbk.

3. Untuk mengetahui dan menganalisis pengaruh budaya organisasi dan kepuasan kerja terhadap kinerja karyawan PT. Bank Tabungan Negara (Persero) Tbk.

\section{TINJAUAN PUSTAKA \\ Budaya Organisasi}

Budaya organisasi adalah suatu karakteristik yang ada pada sebuah organisasi dan menjadi pedoman organisasi tersebut sehingga membedakannya dengan organisasi lainnya. Dengan kata lain, budaya organisasi adalah norma perilaku dan nilai-nilai yang dipahami dan diterima oleh semua anggota organisasi dan digunakan sebagai dasar dalam aturan perilaku dalam organisasi tersebut.

Sjahril (2015:44) budaya organisasi adalah suatu konsep (concept) yang sangat bervariasi, terbukti dari adanya sekian banyak definisi yang berbeda-beda yang dapat ditemukan dalam kepustakaan. Hal ini disebabkan oleh berbagai pandangan, pendekatan, metode penelitian, minat masingmasing yang berkepentingan dari berbagai kalangan, baik dari kalangan akademisi maupun praktisi. Disamping itu juga karena sumbernya yaitu disiplin antropologi, yang sehingga sekarang belum dapat menghasilkan satu definisi yang dapat diterima oleh para peminat atau pakar dalam bidang ini.

Husein (2010:207) mengatakan budaya organisasi adalah suatu sistem nilai dan keyakinan bersama yang diambil dari pola kebiasaan dan falsafah dasar pendirinya yang kemudian berinteraksi menjadi norma-norma, dimana norma tersebut dipakai sebagai pedoman cara berpikir dan bertindak dalam upaya mencapai tujuan bersama. Suharsono. (2012:190) menyatakan bahwa budaya organisasi adalah perilaku konvensional masyarakatnya dan mempengaruhi perilaku anggotanya meskipun sebagaian besar tidak

disadarinya. Darmawan (2013:143) mengatakan bahwa budaya organisasi merupakan suatu sistem dari makna atau arti bersama yang dianut para anggotanya yang membedakan organisasi dari organisasi lain.

Berdasarkan beberapa pandangan di atas, maka dapat disimpulkan bahwa budaya organisasi merupakan keyakinan dan nilai bersama yang dianut oleh anggota di dalam organisasi dan sebagai pedoman dalam menjalankan kegiatan di dalam organisasi, yang mengarah pada perilaku-perilaku yang dianggap tepat dan menjadi pembeda dari organisasi yang satu dengan organisasi yang lainnya. Budaya organisasi merupakan seperangkat nilai-nilai dan norma-norma yang telah relatif lama berlaku serta dianut besamasama oleh setiap anggota organisasi (karyawan) sebagai norma perilaku dalam bertindak dan menyelesaikan masalah-masalah organisasi (perusahaan).

\section{Kepuasan Kerja}

Pada dasarnya kepuasan kerja (job satisfaction) merupakan hal yang bersifat individual karena setiap individu akan memiliki tingkat kepuasan yang berbeda-beda 
sesuai dengan nilai-nilai yang berlaku dalam diri setiap individu. Semakin banyak aspek dalam pekerjaan yang sesuai dengan keinginan individu, maka semakin tinggi tingkat kepuasan yang dirasakan. Ada pernyataan yang mengatakan bahwa kepuasan adalah suatu perasaan menyenangkan merupakan hasil dari persepsi individu dalam rangka menyelesaikan tugas atau memenuhi kebutuhannya untuk memperoleh nilai-nilai kerja yang penting bagi dirinya.

Sopiah (2018:170) juga memberikan definisi bahwa kepuasan kerja adalah suatu ungkapan emosional yang bersifat positif atau menyenangkan, sebagai hasil dari penilaian terhadap suatu pekerjaan atau pengalaman kerja. Rachmawati (2018:97) bahwa perasaanperasaan yang berhubungan dengan kepuasan atau ketidak puasan kerja cenderung lebih mencerminkan penaksiran dari karyawan yang berhubungan dengan pengalaman-pengalaman kerja pada waktu sekarang dan masa lalu dari pada harapan-harapan untuk masa yang akan datang.

Sutrisno (2011:75) mengemukakan kepuasan kerja adalah keadaan emosional yang menyenangkan atau tidak menyenangkan bagi para karyawan memandang pekerjaan mereka. Kepuasan kerja mencerminkan perasaaan seseorang terhadap pekerjaanya dan segala sesuatu yang dihadapi di lingkungan kerjanya. Karyawan yang tidak memperoleh kepuasan kerja tidak akan pernah mencapai kepuasan psikologis dan akhirnya akan timbul sikap atau tingkah laku negatif dan pada gilirannya akan dapat menimbulkan frustasi. Sebaliknya karyawan yang terpuaskan akan dapat bekerja dengan baik, penuh semangat, aktif, dan dapat berprestasi lebih baik dari karyawan yang tidak memperoleh kepuasan kerja.

Indriyani (2012:6) bependapat bahwa kepuasan kerja merupakan seperangkat perasaan karyawan tentang menyenangkan atau tidaknya pekerjaan mereka. Kepuasan kerja merupakan respon seseorang terhadap bermacam-macam lingkungan kerja yang dihadapinya. Respon seseorang meliputi respon terhadap komunikasi organisasi, supervisor, kompensasi, promosi, teman sekerja, kebijaksanaan organisasi dan hubungan interpersonal dalam organisasi.

Dari beberapa definisi di atas maka ditarik kesimpulan bahwa kepuasan kerja adalah emosi atau perasaan seseorang yang senang atau tidak senang dengan pekerjaan mereka. Serta adanya harapan, keinginan dan tuntutan dari karyawan dengan realitas yang dirasakan dan didapatkan di tempat kerja. Sehingga hal ini dapat menimbulkan perasaan puas atau tidak puasnya seseorang. Kepuasan kerja merupakan cerminan dari perasaan karyawan terhadap pekerjaanya. Hal ini tampak dalam sikap karyawan yang memiliki tingkat kepuasan yang tinggi akan memperlihatkan sikap positif terhadap pekerjaannya. Sebaliknya karyawan yang tidak puas dengan pekerjaannya akan bersikap negatif terhadap pekerjaannya.

\section{Kinerja}

Menurut Rachmawati (2018:53) pengertian kinerja adalah merupakan kata benda (noun) yang artinya : sesuatu yang dicapai, prestasi yang diperlihatkan, kemampuan kerja. Menurut Winardi (2014:131) bahwa kinerja pegawai adalah kemampuan pegawai untuk meningkatkan hasil produktivitas kerja ke tahap yang lebih baik dari yang dicapai sebelumnya. Dalam meningkatkan kinerja pegawai seorang pimpinan dapat melakukannya dengan memotivasi bawahannya. Seorang pimpinan tidak semata-mata bertujuan untuk mencapai keuntungan demi keuntungan itu sendiri, tetapi karena ia mempunyai keinginan yang kuat untuk berprestasi. Keuntungan atau laba hanyalah suatu ukuran sederhana yang menunjukkan seberapa baik pekerjaan yang telah dilakukan, tetapi tidak sepenting tujuan itu sendiri.

Dharma (2011:1) menyatakan bahwa kinerja adalah suatu yang dihasilkan atau yang diberikan seseorang atau sekelompok orang. Dalam pengertian ini kinerja merupakan hasil yang dicapai seseorang atau beberapa orang secara bersama-sama dalam melakukan

pekerjaan. Dengan demikian kinerja merupakan hasil kerja yang dicapai seseorang dalam menjalankan tugas-tugas yang diberikan 
kepadanya yang didasrkan pada kecakapan, pengalaman, kesungguhan, dan waktu".

Berdasarkan pengertian di atas pengertian tersebut maka dapat diketahui bahwa kinerja merupakan gabungan dari kemampuan dan minat pekerja, peran serta motivasi seorang pekerja juga menentukan kinerjanya. Semakin tinggi ketiga faktor tersebut semakin besarlah kinerja pegawai tesebut.

\section{METODE PENELITIAN}

Penelitian ini dilaksanakan di PT. Bank Tabungan Negara Cabang Medan, JL Pemuda No.10-A Medan, Sumatera Utara pada bulan Februari 2021 sampai dengan Mei 2021.

Populasi dalam penelitian ini adalah semua karyawan PT. Bank Tabungan Negara Cabang Medan yang berjumlah 162 karyawan. Dalam penelitian ini sampel yang akan diambil sebesar 62 responden. Sedangkan teknik pengambilan sampel yang digunakan adalah Probability sampling dengan proportionate stratified random.

Batasan operasional dalam peneltian ini adalah ada dua variabel yang di gunakan dalam penelitian ini, yaitu variabel independen atau bebas yang selanjutnya dinyatakan dengan symbol (X) dan variabel dependen/ terikat yang dinyatakan sebagai symbol (Y).

Variabel terikat (dependent) dalam penelitian ini adalah Kinerja (Y). Variabel bebas (independent) yang terkait dalam pembahasan ini adalah berupa Budaya Organisasi $\left(\mathrm{X}_{1}\right)$ dan Kepuasan Kerja $\left(\mathrm{X}_{2}\right)$ dimana variabel bebas tersebut di duga mempengaruhi variabel terikat.

Teknik pengumpulan data dalam penelitian ini menggunakan teknik wawancara, penyebaran kuesioner/angket, studi dokumentasi dan studi kepustakaan.

Ada tiga pengujian yang dilakukan dalam penelitian ini untuk pengukur kualitas instrumen, yaitu :

1. Uji Validitas dan Uji Reliabilitas

2. Uji Asumsi Klasik

3. Uji Hipotesis

\section{HASIL DAN PEMBAHASAN}

\section{A. UJI VALIDITAS}

Uji validitas dilakukan terhadap isi dari suatu instrumen, tujuan dilakukannya pengujian ini adalah untuk mengukur ketetapan instrumen yang digunakan dalam suatu penelitian. Item kuesioner dikatakan valid apabila nilai rhitung $>$ rtabel dengan $n=25$ adalah 0,396 .

1) BUDAYA ORGANISASI ( $\left.X_{1}\right)$

Berdasarkan data dapat diperoleh hasil uji validitas untuk item kuesioner Budaya Organisasi $\left(\mathrm{X}_{1}\right)$ adalah sebagai berikut :

Tabel 1 Hasil Validitas Budaya Organisasi (X1)

\begin{tabular}{|c|c|c|c|}
\hline Pernyataan & $\begin{array}{c}\text { Nilai } \\
\text { Korelasi } \\
(\mathbf{r})\end{array}$ & r-tabel & Kesimpulan \\
\hline 1 & 0.539 & 0,396 & Valid \\
\hline 2 & 0.680 & 0,396 & Valid \\
\hline 3 & 0.736 & 0,396 & Valid \\
\hline 4 & 0.805 & 0,396 & Valid \\
\hline 5 & 0.733 & 0,396 & Valid \\
\hline 6 & 0.701 & 0,396 & Valid \\
\hline 7 & 0.700 & 0,396 & Valid \\
\hline 8 & 0.573 & 0,396 & Valid \\
\hline 9 & 0.444 & 0,396 & Valid \\
\hline 10 & 0.489 & 0,396 & Valid \\
\hline
\end{tabular}

Berdasarkan tabel diatas, maka dapat dilihat bahwa nilai korelasi seluruh item pernyataan untuk budaya organisasi $\left(\mathrm{X}_{1}\right)$ lebih besar dari 0,396. Hal ini menunjukkan bahwa kesepuluh item adalah valid.

2) KEPUASAN KERJA ( $\left.\mathbf{X}_{2}\right)$ Berdasarkan data dapat diperoleh hasil uji validitas untuk item kuesioner Kepuasan Kerja (X2) adalah sebagai berikut :

Tabel 2 Hasil Validitas Kepuasan Kerja $\left(\mathbf{X}_{2}\right)$

\begin{tabular}{|c|c|c|c|}
\hline Pernyataan & $\begin{array}{c}\text { Nilai } \\
\text { Korelasi } \\
(\mathbf{r})\end{array}$ & r-tabel & Kesimpulan \\
\hline 1 & 0.543 & 0,396 & Valid \\
\hline 2 & 0.691 & 0,396 & Valid \\
\hline 3 & 0.741 & 0,396 & Valid \\
\hline 4 & 0.799 & 0,396 & Valid \\
\hline 5 & 0.724 & 0,396 & Valid \\
\hline 6 & 0.650 & 0,396 & Valid \\
\hline 7 & 0.709 & 0,396 & Valid \\
\hline 8 & 0.532 & 0,396 & Valid \\
\hline 9 & 0.422 & 0,396 & Valid \\
\hline 10 & 0.459 & 0,396 & Valid \\
\hline
\end{tabular}


Berdasarkan tabel diatas, maka dapat dilihat bahwa nilai korelasi seluruh item pernyataan untuk variabel Kepuasan Kerja (X2) lebih besar dari 0,396. Hal ini menunjukkan bahwa kesepuluh item adalah valid

\section{3) KINERJA (Y)}

Berdasarkan data dapat diperoleh hasil uji validitas untuk item kuesioner Kinerja (Y) adalah sebagai berikut :

Tabel 3 Hasil Validitas Kinerja (Y)

\begin{tabular}{|c|c|r|c|}
\hline Pernyataan & \multicolumn{1}{|l|}{$\begin{array}{l}\text { Nilai } \\
\text { Korelasi } \\
\text { (r) }\end{array}$} & r-tabel & Kesimpulan \\
\hline 1 & 0.604 & 0,396 & Valid \\
\hline 2 & 0.421 & 0,396 & Valid \\
\hline 3 & 0.661 & 0,396 & Valid \\
\hline 4 & 0.563 & 0,396 & Valid \\
\hline 5 & 0.611 & 0,396 & Valid \\
\hline 6 & 0.518 & 0,396 & Valid \\
\hline 7 & 0.659 & 0,396 & Valid \\
\hline 8 & 0.763 & 0,396 & Valid \\
\hline 9 & 0.648 & 0,396 & Valid \\
\hline 10 & 0.634 & 0,396 & Valid \\
\hline
\end{tabular}

Berdasarkan tabel diatas, maka dapat dilihat bahwa nilai korelasi seluruh item pernyataan untuk variabel Kinerja (Y) lebih besar dari 0,396. Hal ini menunjukkan bahwa kesepuluh item adalah valid.

\section{B. UJI RELIABILITAS}

Uji reliabilitas dilakukan terhadap item pertanyaan yang dinyatakan valid. Suatu variabel dikatakan reliabel atau handal jika jawaban terhadap pertanyaan selalu konsisten. Berdasarkan hasil perhitungan uji reliabilitas variabel budaya organisasi, kepuasan kerja dan kinerja maka diperoleh hasil sebagai berikut :

\section{Tabel 4 Hasil Uji Reliabilitas}

\begin{tabular}{llccl}
$\mathbf{N}$ & Variabel & $\begin{array}{c}\text { Cronbach's } \\
\text { Alpha }\end{array}$ & r teori & Kriteria \\
\hline 1 & Budaya Organisasi $\left(\mathrm{X}_{1}\right)$ & 0,895 & 0.70 & Reliabel \\
2 & Kepuasan Kerja $\left(\mathrm{X}_{2}\right)$ & 0,890 & 0.70 & Reliabel \\
3 & Kinerja (Y) & 0,879 & 0.70 & Reliabel \\
\hline
\end{tabular}

Berdasarkan tabel diatas, uji reliabilitas dilakukan terhadap item pertanyaan yang dinyatakan valid. Suatu variabel dikatakan reliabel atau handal jika jawaban terhadap pertanyaan selalu konsisten. Jadi hasil koefisien reliabilitas variabel budaya organisasi adalah sebesar 0,895, variabel kepuasan kerja adalah sebesar 0,890,dan variabel kinerja adalah sebesar 0,879 , ternyata memiliki nilai "Cronbach's Alpha" > 0,70, sesuai dengan dasar pengambilan keputusan uji reliabilitas yang berarti ketiga variabel dinyatakan reliabel atau memenuhi persyaratan.

\section{UJI ASUMSI KLASIK 1) UJI NORMALITAS}

Uji normalitas memiliki tujuan untuk mengetahui apakah dalam model regresi variabel dependen dan independen yang digunakan berdistribusi dengan normal atau tidak atau tidak mempunyai distribusi normal melalui analisis grafik dan uji statistik. Pembuktian apakah data yang digunakan dapat berdistribusi dengan normal yaitu dengan melihat pada grafik histogram dan probability plot. Dapat dikatakan normal jika titik-titik menyebar disekitar garis diagonal dan mengikuti arah garis diagonal. Hasil uji normalitas dalam penelitian ini adalah:

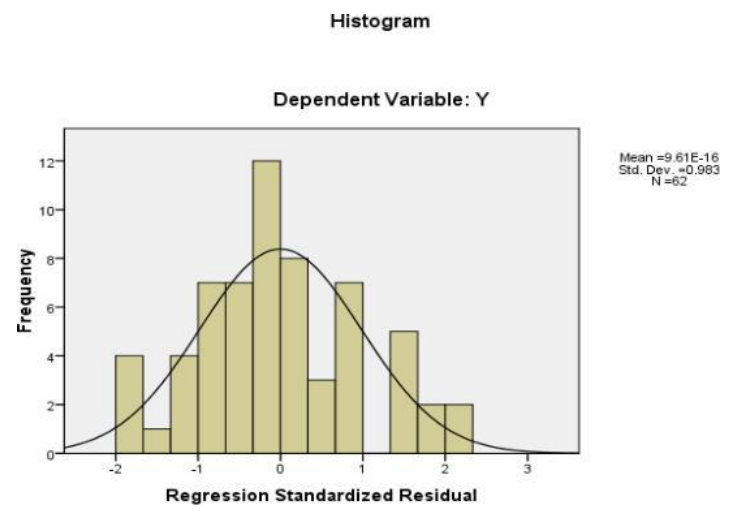

\section{Gambar 1 Diagram Histogram}

Berdasarkan gambar diatas dapat disimpulkan bahwa data yang digunakan menunjukkan normal hal ini terlihat dari pola data membentuk lonceng dan berada ditengahtengah sehingga dapat disimpulkan data tersebut normal. 
Normal P-P Plot of Regression Standardized Residual

Dependent Variable: $Y$

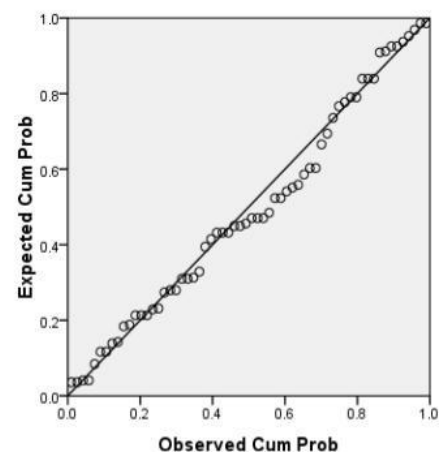

Gambar 2 Grafik Normal P-Plot

Pada grafik P-Plot, data menyebar disekitar garis diagonal dan mengikuti arah garis diagonal maka model regresi memenuhi asumsi normalitas. Pada gambar grafik tersebut memperlihatkan bahwa pola distribusi cenderung normal, data menunjukkan titiktitik menyebar disekitar garis diagonal dan mengikuti arah garis diagonal, maka model regresi memenuhi asumsi normalitas.

\section{2) UJI MULTIKOLINIERITAS}

Uji multikolinearitas bertujuan untuk menguji apakah model regresi ditemukan adanya korelasi antar variabel bebas (independent). Model regresi yang baik adalah apabila tidak terjadi korelasi diantara variabel bebas. Apabila terjadi saling berkorelasi, maka variabel-variabel tersebut tidak ortogonal. Untuk melihat terjadinya multikolinieritas dapat dilihat dari besarnya nilai VIF sebagai berikut.

\section{Tabel 6 Hasil Uji Multikolinieritas}

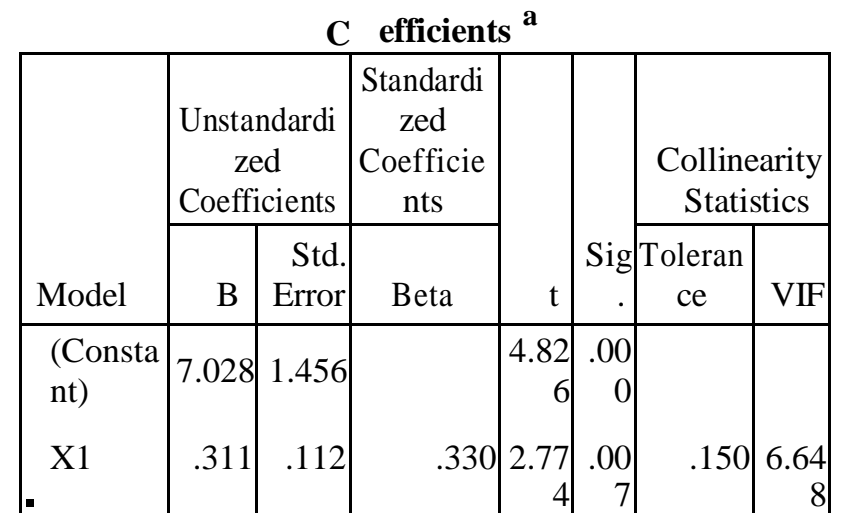

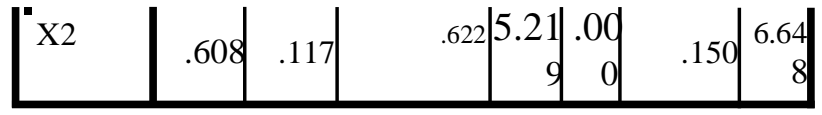

Berdasarkan tabel di atas terlihat bahwa besarnya nilai VIF masing-masing variabel adalah 6,648 dan 6,648 dimana $<10$ yang berarti kolinieritas dapat ditoleransi.

\section{3) UJI HETEROSKEDASTISITAS}

Uji heteroskedastisitas bertujuan untuk menguji dalam model regresi terjadi ketidaksamaan varians dari residual satu pengamatan ke pengamatan yang lain. Cara untuk mengetahui terjadi heteroskedastisitas atau tidak yaitu dengan melihat Grafik Plot antara nilai prediksi variabel dependen yaitu ZPRED dengan residualnya SRESID. Tidak terjadi heteroskedastisitas yaitu apabila tidak ada pola yang jelas, serta titik-titik menyebar di atas dan di bawah angka 0 pada sumbu Y. Berikut adalah grafik scatterplot dari uji heteroskedastisitas :

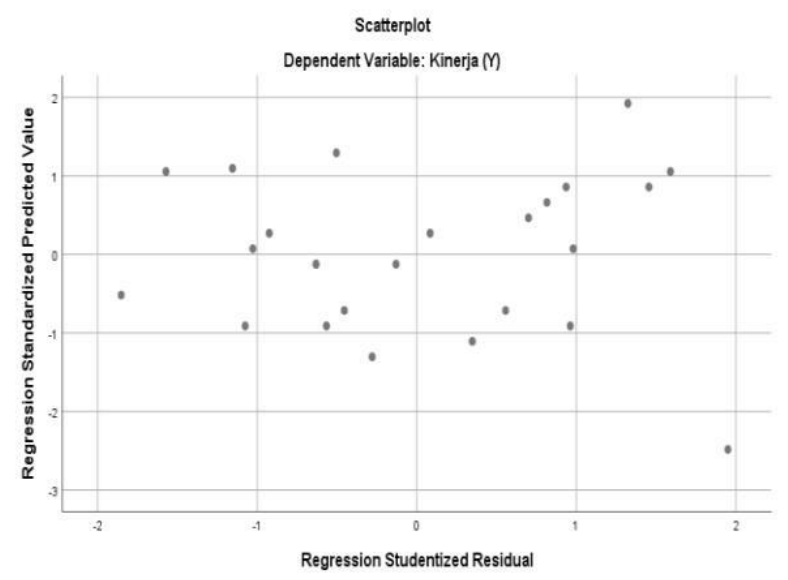

\section{Gambar 3 Grafik Scatterplot}

Berdasarkan gambar diatas, terlihat bawah tidak ada pola yang jelas serta titik-titik tersebut menyebar di atas dan dibawah angka 0 pada sumbu Y. Hal ini menunjukkan bahwa data dalam penelitian ini tidak terjadi heteroskedastisitas.

\section{4) ANALISIS REGRESI LINEAR BERGANDA}

Hasil pengujian terhadap model regresi berganda terhadap variabel Budaya Organisasi $\left(\mathrm{X}_{1}\right)$ dan Kepuasan Kerja $\left(\mathrm{X}_{2}\right)$ yang mempengaruhi Kinerja (Y) dapat dilihat dalam tabel berikut : 
Tabel 7 Hasil Analisis Regresi Linear Berganda

\begin{tabular}{|c|c|c|c|c|c|c|c|}
\hline \multirow[b]{3}{*}{ Model } & \multicolumn{4}{|c|}{ C efficients ${ }^{a}$} & & \multirow{2}{*}{\multicolumn{2}{|c|}{$\begin{array}{r}\text { Collinearity } \\
\text { Statistics }\end{array}$}} \\
\hline & \multicolumn{2}{|c|}{$\begin{array}{c}\text { Unstandardi } \\
\text { zed } \\
\text { Coefficients }\end{array}$} & \begin{tabular}{|c} 
Standardi \\
zed \\
Coefficie \\
nts
\end{tabular} & \multirow[b]{2}{*}{$\mathrm{t}$} & \multirow[b]{2}{*}{$\mathrm{Sig}$} & & \\
\hline & B & $\begin{array}{r}\text { Std. } \\
\text { Error }\end{array}$ & Beta & & & $\begin{array}{c}\text { Tolera } \\
\text { nce }\end{array}$ & VIF \\
\hline $\begin{array}{c}1 \text { (Consta } \\
\text { nt) }\end{array}$ & 7.028 & 1.456 & & $\begin{array}{r}4.8 \\
26\end{array}$ & $\begin{array}{r}.00 \\
0\end{array}$ & & \\
\hline X1 & .311 & .112 & .330 & $\begin{array}{r}2.7 \\
74\end{array}$ & $\begin{array}{r}.00 \\
7\end{array}$ & .150 & $\begin{array}{r}6.6 \\
48\end{array}$ \\
\hline $\mathrm{X} 2$ & .608 & .117 & .622 & $\begin{array}{r}5.2 \\
19\end{array}$ & $\begin{array}{r}.00 \\
0\end{array}$ & .150 & $\begin{array}{r}6.6 \\
48\end{array}$ \\
\hline
\end{tabular}

a. Dependent

Variable: $\mathrm{Y}$

Dengan memperhatikan model regresi dan hasil regresi linier berganda maka didapat persamaan faktor-faktor yang mempengaruhi Kinerja sebagai berikut :

$$
Y=1.456+0,112 X_{1}+0,117 X_{2}+e
$$

\section{UJI HIPOTESIS}

\section{1) UJI T (PARSIAL)}

Uji t menunjukkan seberapa jauh pengaruh satu variabel independen secara individual dalam menerangan variasi variabel dependen. Uji t pada penelitian ini dilakukan dengan membandingkan nilai signifikansi $t$ dengan $\alpha$ sebesar 0.05 .

\section{Tabel 8 Hasil Uji T (Parsial)}

\begin{tabular}{|c|c|c|c|c|c|c|c|}
\hline \multirow[b]{3}{*}{ Model } & \multicolumn{4}{|c|}{$\mathrm{C}$ efficients ${ }^{\mathrm{a}}$} & & \multirow{2}{*}{\multicolumn{2}{|c|}{$\begin{array}{c}\text { Collinearity } \\
\text { Statistics }\end{array}$}} \\
\hline & \multicolumn{2}{|c|}{\begin{tabular}{|c|} 
Unstandardi \\
zed \\
Coefficients
\end{tabular}} & \multirow{2}{*}{$\begin{array}{c}\begin{array}{c}\text { Standardi } \\
\text { zed } \\
\text { Coefficie } \\
\text { nts }\end{array} \\
\text { Beta }\end{array}$} & \multirow[b]{2}{*}{$\mathrm{t}$} & \multirow[b]{2}{*}{ Sig } & & \\
\hline & B & $\begin{array}{r}\text { Std. } \\
\text { Error }\end{array}$ & & & & $\begin{array}{c}\text { Tolera } \\
\text { nce }\end{array}$ & VIF \\
\hline $\begin{array}{c}1 \text { (Consta } \\
\text { nt) }\end{array}$ & 7.028 & 1.456 & & $\begin{array}{r}4.8 \\
26\end{array}$ & $\begin{array}{r}.00 \\
0\end{array}$ & & \\
\hline $\mathrm{X} 1$ & .311 & .112 & .330 & $\begin{array}{r}2.7 \\
74\end{array}$ & $\begin{array}{r}.00 \\
7\end{array}$ & .150 & $\begin{array}{r}6.6 \\
48\end{array}$ \\
\hline $\mathrm{X} 2$ & .608 & .117 & .622 & $\begin{array}{r}5.2 \\
19\end{array}$ & $\begin{array}{r}.00 \\
0\end{array}$ & .150 & $\begin{array}{r}6.6 \\
48\end{array}$ \\
\hline
\end{tabular}

a. Dependent

Variable: $\mathrm{Y}$

Berdasarkan hasil uji $\mathrm{t}$ diatas diperoleh nilai $\mathrm{t}$ tabel $=$ pada $\mathrm{n}-3(45-3)$ adalah 42 pada taraf signifikan 5\% (0,05) adalah 2,01808. Maka dengan demikian untuk mengetahui secara parsial dapat disusun persamaan regresi berganda sebagai berikut:

1. Nilai tbudaya organisasi $=2,774$, sedangkan tabel dengan dk 62 sebesar 1,670 maka thitung $\geq$ tabel dengan demikian secara parsial ada pengaruh yang signifikan antara budaya organisasi terhadap kinerja, maka hipotesis 1 diterima kebenarannya.

2. Nilai tkepuasan kerja $=5,219$ sedangkan tabel dengan dk 62 sebesar 1,670 maka thitung > tabel dengan demikian secara parsial ada pengaruh yang signifikan antara kepuasan kerja terhadap kinerja, maka hipotesis 2 diterima kebenarannya.

\section{2) UJI F (SIMULTAN)}

Uji $F$ bertujuan untuk mengetahui pengaruh variabel independen secara simultan terhadap variabel dependen. Berikut adalah tabel output SPSS dari uji F.

\section{Tabel 9 Hasil Uji F (Simultan)}

$$
\text { AN OVA }{ }^{\text {b }}
$$

\begin{tabular}{|l|r|r|r|c|c|}
\hline Model & $\begin{array}{r}\text { Sum of } \\
\text { Squares }\end{array}$ & df & $\begin{array}{r}\text { Mean } \\
\text { Square }\end{array}$ & F & Sig. \\
\hline 1 Regression & 965.259 & 2 & 482.630 & 204.835 & $.000^{\mathrm{a}}$ \\
Residual & 139.015 & 59 & 2.356 & & \\
$\quad$ Total & 1104.274 & 61 & & & \\
\hline
\end{tabular}

a. Predictors: (Constant),

$\mathrm{X} 2, \mathrm{X} 1$

b. Dependent Variable: Y

Hasil perhitungan uji $\mathrm{F}$ pada tabel diatas dengan statistik manual diperoleh nilai $F$ hitung $=204,83$ sedangkan dengan menggunakan tingkat signifikansi $5 \%$ maka nilai $\mathrm{F}$ tabel dengan dengan $\mathrm{dk}$ pembilang 2 dan dk penyebut 62 adalah sebesar 2,37, maka Fhitung > Ftabel, yaitu 204,83>2,37. Dengan demikian budaya organisasi dan kepuasan kerja secara simultan memiliki pengaruh terhadap kinerja pegawai. Sedangkan dengan menggunakan SPSS 21 diperoleh tingkat signifikansi sebesar $0,00<0,05$ ini menandakan bahwa budaya organisasi $\left(\mathrm{X}_{1}\right)$, dan kepuasan kerja (X2) secara bersama berpengaruh terhadap kinerja pegawai (Y).

\section{3) KOEFISIEN DETERMINASI $\left(\mathbf{R}^{2}\right)$}

Untuk menunjukkan berapa persen pengaruh Budaya Organisasi dan Kepuasan Kerja secara bersama-sama terhadap Kinerja 
digunakan koefisien determinasi. Uji Koefisien Determinasi bertujuan untuk mengukur sebesar besar kemampuan model dalam menerangkan variasi variabel dependen. Jika nilai $\mathrm{R}^{2}$ kecil berarti kemampuan variabel-variabel independen dalam menjelaskan variasi variabel dependen menjadi sangat terbatas. Kelemahan penggunaan $\mathrm{R}^{2}$ adalah bias terhadap jumlah variabel independen yang dimasukkan ke dalam model. Oleh karena itu, maka dianjurkan untuk menggunakan nilai Adjusted $\mathrm{R}^{2}$ pada saat mengevaluasi mana model regresi terbaik (Ghozali, 2011: 97). Hasil Uji Koefisien Determinasi ditunjukkan dalam tabel sebagai berikut :

\section{Tabel 10 Hasil Uji Koefisien Determinasi} $\left(\mathbf{R}^{2}\right)$

\begin{tabular}{|c|c|c|c|c|c|c|c|c|c|}
\hline \multirow[b]{3}{*}{$\begin{array}{l}\text { Mod } \\
\text { el }\end{array}$} & \multicolumn{9}{|c|}{ Model Summary ${ }^{b}$} \\
\hline & \multirow{2}{*}{\multicolumn{2}{|c|}{$\mathrm{R}\left|\begin{array}{c}\mathrm{R} \\
\text { Squa } \\
\text { re }\end{array}\right|$}} & \multirow[b]{2}{*}{$\begin{array}{c}\text { Adjust } \\
\text { ed R } \\
\text { Squar } \\
\text { e }\end{array}$} & \multirow[b]{2}{*}{\begin{tabular}{|} 
Std. \\
Error \\
of the \\
Estim \\
ate
\end{tabular}} & \multicolumn{5}{|c|}{ Change Statistics } \\
\hline & & & & & \begin{tabular}{|c}
$\mathrm{R}$ \\
Squa \\
re \\
Chan \\
ge
\end{tabular} & $\begin{array}{c}\text { F } \\
\text { Chan } \\
\text { ge }\end{array}$ & $\begin{array}{r}\mathrm{df} \\
1\end{array}$ & $\begin{array}{r}\mathrm{df} \\
2\end{array}$ & $\begin{array}{l}\text { Sig. } \\
\text { F } \\
\text { Chan } \\
\text { ge }\end{array}$ \\
\hline 1 & $\begin{array}{r}.93 \\
5^{\mathrm{a}}\end{array}$ & .874 & .870 & 1.535 & .874 & $\begin{array}{r}204.8 \\
35\end{array}$ & 2 & 5 & .000 \\
\hline
\end{tabular}

a. Predictors:

(Constant), X2, X1

b. Dependent

Variable: Y

Dari tabel diatas dapat diketahui hasil koefisien korelasi atau R sebesar 0,935 hal ini menunjukkan bahwa pengaruh budaya organisasi dan kepuasan kerja terhadap kinerja karyawan PT. Bank Tabungan Negara (Persero) Tbk. Kantor Cabang Medan mempunyai pengaruh yang positif yaitu sebesar 93,5\%. Hasil Koefisien Determinasi atau $\mathrm{R}$ square $\left(\mathrm{R}^{2}\right)$ adalah 0,874 yang menunjukan bahwa $87,4 \%$ kinerja karyawan PT. Bank Tabungan Negara (Persero) Tbk. Kantor Cabang Medan dipengaruhi oleh budaya organisasi dan kepuasan kerja sementara sisanya sebesar $12,6 \%$ dipengaruhi oleh sebab-sebab lain yang tidak diteliti dalam penelitian ini.

\section{PENGARUH BUDAYA ORGANISASI TERHADAP KINERJA}

Berdasarkan hasil uji statistik dengan menggunakan multiple regression model untuk melihat pengaruh budaya organisasi terhadap kinerja, menunjukkan bahwa terdapat pengaruh positif variabel budaya organisasi $\left(\mathrm{X}_{1}\right)$, terhadap variabel Kinerja (Y) yang ditunjukkan tbudaya organisasi $=2,774$, sedangkan tabel dengan dk 62 sebesar 1,670 maka thitung $\geq$ tabel. dengan demikian secara parsial ada pengaruh yang signifikan antara budaya organisasi terhadap kinerja.

Budaya organisasi yang baik akan mampu meningkatkan kinerja dan sebaliknya inovasi yang buruk akan memperburuk kinerja pegawai. Pegawai yang memiliki inovasi yang baik akan mendorong peningkatan kinerja. Hal ini sejalan dengan penelitian yang pernah dilakukan oleh peneliti sebelumnya oleh Mokodompit (2016) menyatakan, setiap peningkatan budaya organisasi kearah yang lebih kondusif akan memberikan sumbangan yang sangat berarti untuk peningkatan kinerja karyawan. Hal ini juga didukung dengan hasil Appelbaum (dalam Mangkunegara, 2013:45) yang menyatakan bahwa budaya organisasi antara lain orientasi pada proses dan hasil,

orientasi karyawan dan pekerjaan, profesionalisme, sistem manajemen terbuka dan tertutup, evaluasi dan normatif.

\section{PENGARUH KEPUASAN KERJA TERHADAP KINERJA}

Berdasarkan hasil uji statistik terdapat pengaruh positif variabel kepuasan kerja $\left(\mathrm{X}_{2}\right)$ terhadap variabel Kinerja (Y) yang

ditunjukkan nilai tkepuasan kerja $=5,219$ sedangkan tabel dengan dk 62 sebesar 1,670 maka thitung > tabel. Dengan demikian secara parsial ada pengaruh yang signifikan antara kepuasan kerja terhadap kinerja

Penelitian ini juga pernah dilakukan oleh peneliti sebelumnya Satriyawan (2017) menyatakan bahwa budaya organisasi dan kepuasan kerja memberikan pengaruh terhadap kinerja karyawan. Hal ini juga sesuai dengan pendapat Matutina (2015:83) bahwa kepuasan kerja merupakan salah satu ikuran dari kualitas kehidupan dalam organisasi dan 
akan menjadi prediksi yang tidak baik apabila

kepuasan kerja tidak menyebabkan peningkatan kinerja. Indikasi kepuasan kerja biasanya dikaitkan dengan tingkat absensi, tingkat perputaran tenaga kerja, dimana dimana kedua hal tersebut dapat memunculkan cost yang tinggi dalam organisasi sehingga perusahaan sangatlah beralasan secara ekonomi untuk concern terhadap kepuasan kerja, karena sangat mempengaruhi kinerja karyawan dan efektivitas organisasi.

\section{PENGARUH BUDAYA ORGANISASI DAN KEPUASAN KERJA TERHADAP KINERJA KARYAWAN PT. BANK TABUNGAN NEGARA (PERSERO) TBK. KANTOR CABANG MEDAN.}

Berdasarkan pengujian yang dilakukan secara simultan menunjukkan bahwa variabel Budaya Organisasi ( $\mathrm{X}_{1}$ ) dan Kepuasan Kerja $\left(\mathrm{X}_{2}\right)$ berpengaruh terhadap Kinerja Karyawan PT. Bank Tabungan Negara (Persero) Tbk. Kantor Cabang Medan. Dengan nilai nilai Fhitung sebesar 204,83 sedangkan dengan menggunakan tingkat signifikansi 5\% maka nilai Ftabel dengan dengan dk pembilang 2 dan dk penyebut 62 adalah sebesar 2,37, maka Fhitung > Ftabel, yaitu 204,83 > 2,37. Dengan demikian budaya organisasi dan kepuasan kerja secara simultan memiliki pengaruh terhadap kinerja pegawai.

Penelitian ini juga pernah dilakukan oleh peneliti sebelumnya oleh Mokodompit (2016) menjelaskan bahwa secara simultan kedua variabel bebas, budaya organisasi dan kepuasan kerja berpengaruh positif dimana kedua variabel berikut memiliki kaitan yang erat terhadap kinerja karyawan. Budaya Organisasi berpengaruh tetapi tidak signifikan terhadap kinerja karyawan hal tersebut diakibatkan oleh berbagai macam faktor yaitu fasilitas penunjang karyawan seperti peralatan kerja kurang memadai, pemimpin yang kurang mampu mengontrol, informasi dan komunikasi yang tidak efektif hal tersebut dibuktikan dari hasil olah data spss budaya organisasi secara parsial yang ditemukan bahwa budaya organisasi dalam penelitian ini berpengaruh tetapi tidak signifikan. Sebaliknya kepuasan kerja memberikan kontribusi terhadap kinerja karyawan atau berpengaruh positif terhadap kinerja karyawan. Adapun faktor penunjangnya sebagai berikut; perusahaan sering memberikan gaji yang sesuai dan perusahaan menyediakan sebuah reward untuk pengembangan karir bagi karyawan yang berprestasi, hal ini yang membuat kepuasan kerja dalam perusahaan yang diteliti memiliki pengaruh positif terhadap kinerja karyawan.

\section{KESIMPULAN DAN SARAN KESIMPULAN}

Berdasarkan hasil penelitian dan pembahasan, maka dapat diambil suatu simpulan, yaitu :

1. Kinerja karyawan PT. Bank Tabungan Negara (Persero) Tbk Cabang Medan dapat ditingkatkan melalui beberapa faktor, diantaranya adalah faktor budaya organisasi dan kepuasan kerja. Semakin nyaman karyawan terhadap budaya organisasi akan semakin meningkat kinerja nya. Semakin tinggi tingkat kepuasan kerja maka semakin meningkat kinerja karyawan. Hal ini tentu saja akan berpengaruh pada peningkatan laba perusahaan.

2. Secara parsial variabel budaya organisasi dan kepuasan kerja masing-masing memiliki pengaruh yang signifikan terhadap kinerja karyawan.

3. Secara simultan budaya organisasi dan kepuasan kerja memiliki pengaruh signifikan terhadap kinerja karyawan PT. Bank Tabungan Negara (Persero) Tbk Cabang Medan.

\section{SARAN}

Pada penelitian ini, peneliti mengajukan beberapa saran yang dapat digunakan sebagai bahan pertimbangan bagi pihak perusahaan dan peneliti selanjutnya :

1. Diharapkan melalui budaya organisasi yang baik, perusahaan mampu meningkatkan kinerja karyawan nya dan melakukan usaha-usaha penginternalisasian budaya organisasi terutama bagi karyawan yang belum lama bekerja di perusahaan. Banyak hal yang dapat dilakukan dalam penginternalisasian 
tersebut misalnya melakukan kegiatankegiatan formal maupun informal. Perusahaan juga diharapkan harus tanggap akan perubahan-perubahan yang terjadi baik dalam maupun diluar organisasi yang berpengaruh terhadap perubahan budaya.

2. Perusahaan diharapkan agar tetap menjaga terciptanya kepuasan kerja pada karyawan. Perusahaan dapat melakukan analisis langsung terhadap karyawan untuk mengetahui keinginan serta kebutuhan karyawan. Dan menerapkan pemberian reward terhadap karyawan yang berprestasi agar menjadi pendorong dan penyemangat bagi kinerja karyawan.

3. Karena keterbatasan yang dimiliki peneliti, diharapkan kepada peneliti

selanjutnya untuk dapat lebih menyempurnakan penelitian ini dengan mencari faktor-faktor lain yang memiliki pengaruh terhadap kinerja karyawan demi kesempurnaan penelitian.

\section{DAFTAR PUSTAKA}

Arikunto, Suharsimi (2012), Prosedur Penelitian pendekatan suatu praktek, Rhineka Cipta, Jakarta.

Airlangga, Bayu. (2015). Manajemen Sumber Daya Manusia, Erlangga, Jakarta.

Darmawan, Didit. (2013). Prinsip-Prinsip

Perilaku Organisasi. Pena Semesta, Surabaya.

Dharma. Agus, (2011). Manajemen Supervisi. Jakarta: Raja Grafindo Persada.

Foster, Bill. (2011). Pembinaan Untuk Peningkatan Kinerja Karyawan, PPm, Jakarta.

Gandapradja, Permadi . (2004), Dasar dan Prinsip Pengawasan Bank, Gramedia Pustaka Utama, Jakarta.

Gomes, Faustino Cordoso. (2015). Manajemen Sumber Daya Manusia, Andi, Yogyakarta.

Handoko, T. Hani (2014). Manajemen.

BPFE-Yogyakarta.
Hasibuan, Malayu S.P. (2013). Manajemen Sumber Daya Manusia. Bumi Aksara, Jakarta.

Husein, U. (2010). Riset Pemasaran dan Perilaku konsumen. Gramedia Pustaka Utama, Jakarta.

Indriyani, Etty. (2012). Pengaruh Budaya

Organisasi dan Kepuasan Kerja

Terhadapa Kinerja Karyawan dengan

Komitmen Organisasi sebagai

Variabel Intervening pada Workshop

SMK Katholik Santo Mikael Surakarta,

http://ejournal.stieaub.ac.id/index.php/e xc ellent.

Manullang, Marihot (2014). Manajemen Sumber Daya Manusia, BPFE, Yogyakarta.

Mangkunegara, Anwar Prabu (2013). Perilaku dan Budaya Organisasi. Refika Aditama, Bandung.

---------; (2015). Manajemen Sumber Daya

Manusia Perusahaan, Remaja Rosda

Karya, Bandung.

Matutina, Domi C. (2015). Manajemen

Sumber Daya Manusia. Gramedia

Widia Sarana Indonesia, Jakarta.

Moekijat. (2015). Manajemen Personalia

Dan Sumber Daya Manusia, Mandar

Maju, Bandung.

Nawawi, Hadari, (2011) Metode Penelitian

Bidang Sosial, Gajah Mada University Press.

Nuraini. (2013). Manajemen Sumber Daya

Manusia, Yayasan Ainisyam, Pekanbaru.

Nurlaila, (2014). Manajemen Sumber Daya Manusia. Penerbit Lepkhair, Jakarta.

Prawirosentono. (2014). Manajemen Sumber Daya Manusia. BPFE, Yogyakarta.

Rachmawati, Ike Kusdyah. (2018), Manajemen Sumber Daya Manusia, Andi, Yogyakarta,

Rivai, Veithzal. (2011). Manajemen Sumber Daya Manusia untuk Perusahaan: dari Teori ke Praktik, RajaGrafindo Persada, Jakarta.

Robbins, S. P., \& Judge, T. (2013). Organizational Behavior, (Edisi Kelimabelas). New Jersey: Pearson 
Education, Inc., Publishing as Prentice

Hall.

Ruky. Achmad S. (2015). Sumber Daya

Manusia Berkualitas, Gramedia

Pustaka Utama, Jakarta..

Siagian, Sondang P. (2013). Manajemen

Sumber Daya Manusia, Bumi Aksara,

Jakarta.

Sopiah. (2018). Perilaku Organisasional.

Andi Offset, Yogyakarta.

Sugiyono, (2014), Metode Penelitian Bisnis,

Alfabeta, Bandung.

Suharsono. (2012).Pengetahuan Dasar

Organisasi. Atma Jaya, Jakarta.

Sutrisno, Edy. (2011). Manajemen Sumber

Daya Manusi. Kencana Prenada Media

Group, Jakarta.

Sjahril, Effendy P, (2015). Budaya

Organisasi Budaya Perusahaan

Budaya Kerja, USU Press, Medan.

Wibowo, (2010). Manajemen Kinerja. Raja

Grafindo Persada, Jakarta.

Winardi, (2014), Pengantar Ilmu

Manajemen, Prenhallindo, Jakarta.

Wirawan. (2015). Manajemen Sumber Daya

Manusia Indonesia. Raja Grafindo

Persada, Jakarta. 